\title{
The Study on Teaching Management Mechanism and Teaching Mode under the Influence of Open Courses
}

\author{
Yu Hongtao* \\ Institute of Automation \\ Shenyang Institute of Engineering \\ Shenyang, China \\ neu970773@sohu.com \\ * Corresponding Author \\ Xue Pengfei \\ Institute of Automation \\ Shenyang Institute of Engineering \\ Shenyang, China \\ Xuepengfei@sie.edu.cn
}

\author{
Bao Yan \\ Institute of Automation \\ Shenyang Institute of Engineering \\ Shenyang, China \\ Baoyan@sie.edu.cn \\ Du Cheng \\ Institute of Automation \\ Shenyang Institute of Engineering \\ Shenyang, China \\ Ducheng@sie.edu.cn
}

\begin{abstract}
Open courses" refers to the network communication courses, which are video courses of excellent university. Teaching management mechanism and teaching mode faced the challenge when a large scale of it appears. Teaching system is imperfect, and teaching mode is not advanced under this condition. The purpose of the study is to optimize the quality of education and teaching, improve teaching; and rebuild the school management. In addition, this paper studys how to rebuild idea of teacher curriculum and stmulate awareness of initiative development so as to promote professional developemnt for teachers. Computer control system is a professional required course, and automation specialty through learning of this course to cultivate students' ability to master the design and implementation of computer control system. At last, we discuss the application of our teaching management mechanism and teaching mode to the course, and teaching results show that the proposed management mechanism and teaching mode are effective.
\end{abstract}

Keywords- open courses; teaching management mechanism; teaching mode; task-driven method; computer control system

\section{INTRODUCTION}

Open course[1] refers to the domestic and foreign outstanding university, which spread on the Internet video courses. It is also called public class. Open course dates back to 1969 , when Britain set up the Open University so as to long-distance teaching[2]. Since the development of Harvard, Yale, Princeton, some foreign universities, such as Oxford, MIT opencourseware are launched on domestic websites. Domestic Tsinghua University, Beijing University and Zhejiang University and other first-class universities open courses are conducted through the network. Open courses benefit the general public indeed, but it poses challenges to the traditional higher education at the same time[3,4]. Fig. 1 shows the structure of this paper .

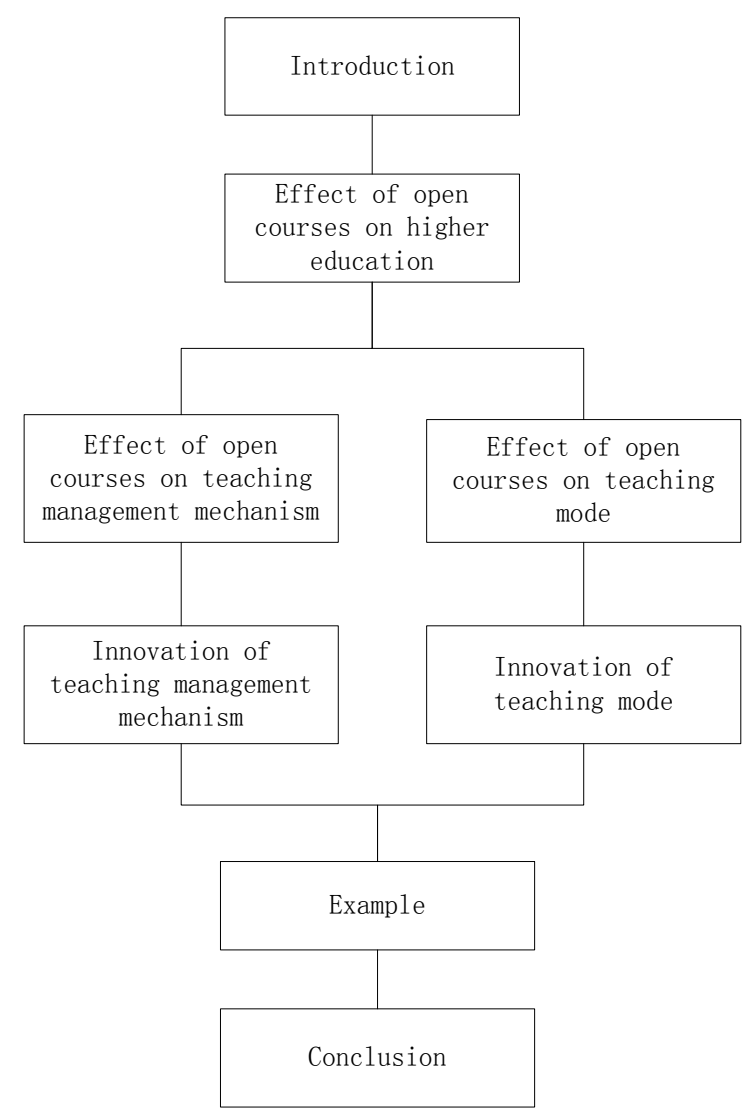

Figure 1.The structure of this paper 


\section{EFFECT OF OPEN COURSES ON HIGHER EDUCATION}

\section{A. Effect of open courses on teaching management mechanism}

Many schools merges or expanses in recent years, which leads to have multi-campus. What's more, graduate students, undergraduates and students are maybe in the same school. Multi-level complex situation causes that many colleges and universities teaching department teaching management mechanism are not perfect[5]. When some problems appeared, they can't be dealt with effectively. Especially under the influence of different open courses, different disciplines have different teaching characteristic, the more difficult to manage with unified system. In addition, the current teaching management mechanism, administrative power is too concentrated, so the efficiency is low. Teaching management mechanism is too rigid, which can't meet the teaching requirement under the influence of open courses.

When open courses appear, many schools do a lot of research on teaching management mechanism so as to develop of teaching[6,7]. But the teaching management mechanism encounters obstacles in the implementation process. On the one hand, the teaching management departments to learn management and operation policy is not value, which doesn't be used in the implementation process. The teaching management department does't supervises and urges each teacher according to the regulations, that's to say, the formulated anagement mechanism is not the actual applied. On the other hand, the teacher does not value in teaching management and operation policy, which will results in the decrease of the teaching quality. As result, it is difficult to draw the students' attention from the open course into the class.

\section{B. Effect of open courses on teaching mode}

Currently many schools opened to the Internet, computers in schools are highly popular. The traditional teaching model has enormous impact under the influence of open courses. Traditional teaching mode is a kind of socalled teaching administrative management mode, and it put emphasize on administrative rules and establishe the specification of the practice teaching management program. This kind of teaching mode to choose unified teaching materials, imply of the unified teaching plan, teaching methods and examination methods[8,9]. The teaching management mode is too rigid, and teachers are too conformist in the teaching process, which is lack of innovation. Under the influence of open course it is very difficult to arouse the enthusiasm of students in class.

\section{INNOVATION OF HIGHER EDUCATION}

To the formulation of teaching management is one of the basic elements of the institutions of higher learning success. Colleges and universities cultivate high-quality students to conform the times and social development, which must adhere to the scientific development concept as the core and the talent training as a fundamental. So teaching management department must build a modern and scientific teaching management operation mechanism[10].
Firstly, the teaching management operating mechanism must be optimized, which vice president of teaching and academic affairs management need attach importance to teach. Teaching management of the secondary school complement operation mechanism, so multi-level teaching management mechanism is formed so that management operation mechanism can avoid power concentrating, and reduce work pressure of staff in the administrative departments. Secondly, teaching management department can improve efficiency by making full use of the Internet, which is convenient for teachers, secondary school and academic communication. Finally, teaching management should strengthen the effective teaching resource sharing and make use of network teaching platform. On the one hand, teachers can share resource sharing between each other so as to improve the quality of teaching. On the other hand, teachers can share learning materials with students; wich can enhance students' learning efficiency. At the same time, through high quality teaching resources of the network platform can also make students feel the teacher's emphasis on teaching, and draw the students to the class.

Execution of the operation mechanism of teaching management is the important elements of the institutions of higher learning success. Perfect teaching management mechanism is only the precondition of success of running a school. The school each department and each leadership under the guidance of teaching vice principal must carry out strictly according to the teaching management mechanism. To the teacher's classroom teaching, teaching calendar, lesson plans and the examination paper carry out inspect regularly, and discussion between eachers with students is organized regularly. Based on teaching feedback, all departments and teachers make adjustments, Tol play the role of the teaching management operating mechanism, make the school each department and really realize the importance of teaching so that teachers can improve the teaching quality.

Keep pace with the times of the operation mechanism of teaching management is the key elements of the continued success of institutions of higher learning. Teaching management mechanism should not be fixed, which should conform to the development of the times. Nowadays internet is height popularity, open courses apear massively, which requires the teaching management operating mechanism reform. First of all, in order to promote the all-round development of students as the theme, Teachers and teaching management department should not only pay attention to imparting theoretical knowledge, but also pay attention to the cultivation of practice ability to make up for the inadequacy of open courses. Secondly, diversification of teaching methods as the guarantee, should not only keep the traditional teaching mode, and to timely, for different courses adopt different teaching methods, especially must pay attention to the interaction between teachers and students, so as to make up for the inadequacy of open course participation is poor Finally, Teachers and teaching management department diversify evaluation oriented, they should not only pay attention to the evaluation result, but also pay attention to process evaluation, so that you can fully give play to the 
role of classroom teaching at the same time, which can reflect the importance of classroom teaching.

\section{APPLICATION EXAMPLES}

Computer control system is a professional required course for automation specialty, through learning of which to cultivate students' ability to master the design and implementation of computer control system. The traditional teaching mode focuses on computer hardware and software design of the control system, the interpretation of the basic theoretical knowledge such as the open course contains a large number of relevant content under the impact. It is difficult to fully arouse the enthusiasm of students in class. We take computer control system as an example to explore teaching mode reform, further attention to cultivate students the basic skills of computer control system of production and debugging, so as to cope with the effects of the open courses of higher education.

Computer control system is developed on the basis of the automatic control system, and the control system using computer to realize function of controller of the traditional continuous control system. We can effectively improve product productivity, and reduce the waste of manpower and material resources by uring computer control system. What's more, we can ensure the quality of products, and realize the working condition of data optimization and control and management integration. Computer control system of the course content is very extensive, which contains the principle of automatic control, electronic technology and microprocessor principle, etc. For the traditional teaching mode teachers put emphasis on the interpretation of theoretical knowledge, and this is too obscure. Furthermore, in open courses there are many similar resources. As a result, teacers mobilize students' learning difficultly in class. Therefore, under the influence of open courses necessary teachers should reform of the teaching mode of computer control system. We use task driven teaching method to computer control system course so as to deal with the effects of the open courses.

Task driven teaching method is a kind of teaching method based on constructivist learning theory. It makes teachers change traditional teaching concept, and teachers take students' cognitive learning as the main body. As a result, the leading multi-dimensional interactive teaching idea is formed. As a research-style teaching mode, the task driven teaching method based on specific tasks related to teaching as the breakthrough point. The purpose is to make the students with a learning task, so as to stimulate students interest and curiosity in learning, help students to clear learning goals. In the process of completing the task can make the students master the basic theory of knowledge, stimulate students seeking knowledge desire; Task driven teaching method can cultivate students' ability to analyze and solve problems, also can strengthen the students' innovative consciousness and the spirit of pioneering spirit. Task driven teaching method, in addition is more suitable for strong operational course, such as computer control system and other practical course.
Especially under the influence of open course, this kind of teaching method should be popularized application.

The step of task driven teaching method in this paper is given in Fig. 2.

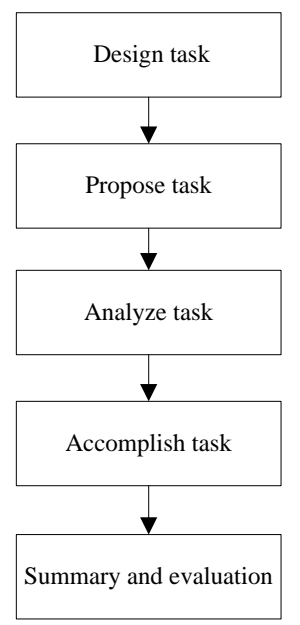

Figure 2.The step of task driven teaching method

\section{A. Design task}

Design task is directly related to the teaching goal of understanding lucid or not. The design of the task must be guided by the syllabus, close around the teaching content, and take full account of the characteristics of the teaching and the students' physical and mental development level. The task must follow the scientific nature, the authenticity, level, affective and interesting principle, and this stage is mainly performed by teachers in preparing section

According to the guidment of control technology and instrument specialty for shenyang institute of engineering the curriculum content of computer control system mainly includes the design method of digital PID control algorithm, the hardware design for computer control system and the software design $\mathrm{n}$, etc. Considering the knowledge coverage and project feasibility, design tasks can be classified as automatic irrigation of the computer control system design, design of computer control system of resistance furnace temperature, $\mathrm{dc}$ motor speed regulation computer control system design, etc. The basic information for computer control system of Shenyang Institute of Engineering is described in TABLE I .

TABLE I . THE BASIC INFORMATION FOR COMPUTER CONTROL SYSTEM

\begin{tabular}{ccccc}
\hline Course title & $\begin{array}{c}\text { Course } \\
\text { properties }\end{array}$ & $\begin{array}{c}\text { Theory } \\
\text { hours }\end{array}$ & $\begin{array}{c}\text { Practice } \\
\text { hours }\end{array}$ & $\begin{array}{c}\text { Total } \\
\text { hours }\end{array}$ \\
\hline $\begin{array}{c}\text { computer } \\
\text { control } \\
\text { system }\end{array}$ & $\begin{array}{c}\text { professional } \\
\text { required course }\end{array}$ & 40 & 12 & 52 \\
\hline
\end{tabular}

\section{B. Propose task and analyze task}

After teache proposes task, task analysis is important for students to complete the task. Task analysis must be guided with teachers as the main line, and teachers should pay attention to appropriate levels of detail for the tasks. it is important to put emphasis on mission requirements for the design, which causes the student to know design intent clearly. The analysis of design for each link must pay 
attention to the point now, as far as possible, that project involves all the teaching content for this course, even if some teaching content in some project does not involve a design steps, teacher does not say explicitly so as to arouse the enthusiasm of students in class. Thus students are forced to analyse project, which can improve the ability of analyzing problems. With computer control system of automatic irrigation system design task as an example is analyzed as follows

Using single-chip microcomputer and programmable controller to control combined with peripheral light sensors, temperature sensor, rain sensors and so on. According to the different conditions of illumination, temperature environment, automatic irrigation implyment, In terms of hardware, the whole hardware block diagram , various device selection and connection methods should be finished by students. In the aspect of software, it is necessary to give the main program and the various parts of the main process and the corresponding subroutine.

\section{Accomplish task}

The completion of the task is directly related to the knowledge, skills, which students use flexiblely or not. The task must be centered on students' independence, and teacher must consider complexity of the task. The task to complete phase based on principles of strength combined with, the students can be divided into 4 to 6 people group. Group tasks plan formulation, data query and task distribution are made by students independently. In this step the teacher don't directly tell the students how to solve the problem, but to guide students to find the way to solve the problem, which can causes the student to set up the confidence to perform the task. At this stage not only can improve student's ability to use knowledge and unity cooperation ability, also can cultivate students form the rigorous scientific attitude, and develop the confidence to overcome difficulties.

For computer control system of automatic irrigation system design example, the first general group usually decomposed into information query, the overall scheme design, hardware design, software design, and project summary and so on several subtasks. Then each person is responsible for a child tasks through group internal negotiation. Finally students collect, sort out their respective responsible subtasks, then they communicate with each other so as to make everyone know the whole tasks.

\section{Summary and evaluation}

Task summary and evaluation are directly related to the success of the task driven teaching method application. Task summary and evaluation must be based on principles of seeking truth from facts, and teacher gives objective evaluation for the completion of the task. Teachers evaluate not only the final results, but also the implementation process. Teachers should evaluate the whole team as well as each member within the team. In this way students' learning subjectivity can be promoted and ability of teachers' teaching can be improved.

For the example of automatic irrigation system design based on computer control system, teachers can give the overall evaluation and the overall scheme firstly. Furthermore, teachers can analyze design of hardware and software. Finally, according to the overall scheme, design of hardware and software, teachers summary the whole task and evaluate each student.

\section{CONCLUSIONS}

Besides that students can acquire knowledge through more ways with the emergence of open courses, the traditional teaching methods and teaching management mechanism face challenge under this condition. The traditional cramming teaching methods method cannot arouse the enthusiasm of students learning fully, and the traditional teaching management mechanism gives rise to inefficiency for teaching operation. In this case, the teaching management mechanism should be improved, and the teacher should analyze the characteristics of the taught courses carefully so that they can reform of teaching mode and evaluation mechanism. Based on computer control system course, this paper discusses the application of taskdriven method. For the practical courses can use the same teaching mode. Moreover, this paper put forward the way to innovation for teaching management mechanism.

\section{ACKNOWLEDGMENT}

This work was supported in part by Liaoning Province Education Science "Twelfth Five Year Plan" project under Grant No.JG14DB292, JG15DB289 and JG15DB301.

\section{REFERENCES}

[1] Rhoads R A, Jennifer B, Brit T. The Open Courseware Movement in Higher Education: Unmasking Power and Raising Questions about the Movement's Democratic Potential[J], Educational Theory, 2013, 63(1):87-110.

[2] Piedra N, Tovar E, Colomopalacios R, Lopezvargas J, Chicaiza J A . Consuming and producing linked open data: the case of OpenCourseWare[J], Program Electronic Library \& Information Systems, 2014, 48(1):16-40(25).

[3] Wang D, Xiong S H, Lin H, Lin L, College G N. Analysis and thought of the quality video open course construction for newlybuilt colleges and universities[J], Journal of Guizhou Normal College, 2014, 2014, 30(3): 20-22.

[4] A Fisher, GB Anderson, R Peng, Leek J. A randomized trial in a massive online open course shows people don't know what a statistically significant relationship looks like, but they can learn[J], Peerj, 2014, 2:e589-e589.

[5] Ittner A, Helman L, Burns M, Mccomas J. Data Drive These Coaches: Literacy Project Merges School Goals with Teachers' Learning Needs [J], Journal of Staff Development, 2015, 36.

[6] Wong S, Pang L, Wong N. Reflections on pedagogical use of blended learning in hospitality education: a case study of teaching human resources management[J], Journal of Teaching in Travel \& Tourism, 2013, 13(3):251-281.

[7] Zhang G, Zhao Y, Li M. The Working Conditions Investigation and Analysis of Traditional Chinese Medicine Colleges and Universities' Teaching Management Team[J], Chinese Medicine Modern Distance Education of China, 2014, 12(15): 143-145.

[8] Zuo D, JieX, Jiang M, Wang L, Liu H T. Construction and Practice of Inquiry Teaching Mode of Polymer Physics, Polymer Bulletin, 2013, 49(12):113-117.

[9] Chen D, Li Z, Wang T. Exploration and practice: A competition based project practice teaching mode[J], Mechatronics, 2014, 24(2):128-138.

[10] Lee O, Im Y. Innovation of Higher Education in the Globalized Era [M], Springer Berlin Heidelberg, 2014:221-247. 